\title{
Kemampuan Problem-solving Skills Calon Guru PAI Berdasarkan Gender dan Grade levels
}

\author{
Adi Fadli \\ Universitas Islam Negeri Mataram, Mataram/NTB, Indonesia \\ adi.fadli@uinmataram.ac.id
}

\begin{abstract}
Abstrak
Penelitian ini bertujuan untuk mendeskripsikan kemampuan problem-solving skills (PSS) calon guru Pendidikan Agama Islam (PAI) berdasarkan gender dan grade levels. Sampel penelitian terdiri dari 100 orang calon guru PAI (60 wanita dan 40 laki-laki) yang ditentukan melalui teknik cluster random sampling. Design penelitian menggunakan cross-sectional survey dan dianalisis dengan uji MANOVA. Instrumen penelitian yang digunakan untuk mengukur kemampuan problem-solving skills (PSS) dengan mengacu pada Instrumen problem solving essay test (PSET) yang dikembangkan oleh Polya. Hasil penelitian membuktikan bahwa; (1) tidak terdapat perbedaan kemampuan problem-solving skills (PSS) calon guru PAI berdasarkan gender; (2) terdapat perbedaan kemampuan problemsolving skills (PSS) calon guru PAI berdasarkan grade levels; (3) grades junior memiliki level PSS yang paling tinggi dibandingkan pada grades freshman dan sophomore.
\end{abstract}

Kata Kunci: problem-solving skills, PAI, gender, grade levels

\begin{abstract}
This study aims to describe the ability of problem-solving skills (PSS) preservice Islamic teachers (PAI) based on gender and grade level. The research sample consisted of 100 PAI teacher candidates (60 women and 40 men) determined through cluster random sampling techniques. The study design used a cross-sectional survey and analyzed it with the MANOVA test. The research instrument used to measure the ability of problem-solving skills (PSS) with reference to the problem-solving instrument essay test (PSET) developed by Polya. The results of the study prove that; (1) there is no difference in the ability of PAI teacher candidates to solve their problem-solving skills based on gender; (2) there are differences in the ability of PAI teacher candidates to solve problem-solving skills (PSS) based on grade levels; (3) junior grades have the highest PSS level compared to freshman and sophomore grades.
\end{abstract}

Keywords: Problem-solving skills, Islamic Education, Gender, Grade levels 


\section{PENDAHULUAN}

Pembelajaran abad 21 memfokuskan pada tercapainya keterampilan abad 21 dengan mengedepankan pengembangan soft skills mahasiswa sehingga dapat bersaing dalam menghadapi era globalisasi. Keterampilan abad 21 yang sangat urgen dimiliki oleh mahasiswa terdiri dari kemampuan pemecahan masalah (problem-solving skills), self eficacy, keterampilan berpikir kritis, scientific attitudes, serta kemampun komunikasi dan berkolaborasi atau bekerjasama (Sanabria \& Jesus, 2017). Akan tetapi, hasil penelitian sebelumnya menunjukkan bahwa kemampuan problem-solving skills (PSS) atau keterampilan pemecahan masalah mahasiswa di level Perguruan Tinggi masih jarang dikembangkan sehingga berpengaruh terhadap rendahnya kemampuan problem-solving skills (PSS) mahasiswa (Irwanto, Saputro, Rohaeti, dan Prodjosantoso, 2018). Terlebih lagi pengembangan problem solving-skills (PSS) calon guru PAI cenderung terabaikan sehingga berdampak pada kurang berkembangnya ketrampilan pemecahan masalah yang dimiliki.

Pengembangan problem-solving skills calon guru PAI sangat urgen untuk dikembangkan sehingga berdampak pada kemudahan pengembangan karier dibutuhkan sebagai bekal dalam menghadapi persaingan di dunia kerja. Kondisi tersebut sangat relevan dengan berbagai penelitian yang membuktikan bahwa keterampilan pemecahan masalah yang dimiliki sangat menentukan kesuksesan hidup seseorang di dunia kerja dan dalam kehidupan bermasyarakat (Temel, 2015). Akan tetapi, secara umum praktek pembelajaran di level Perguruan Tinggi lebih memprioritakan pengembangan prestasi kognitif mahasiswa dibandingkan dengan pengembangan keterampilan pemecahan masalah, keterampilan berpikir kritis, sikap ilmiah, maupun pengembangan keterampilan komunikasi dan kolaborasi khususnya di bidang islamic studies (Ibrahim, Hassan, dan Hashim, 2016; Al-Attas, 1979).

Keterampilan pemecahan masalah merupakan keterampilan dalam mengidentifikasi, menganalisis dan merumuskan pemecahan masalah, serta membuktikan hipotesis dalam rangka penyelesaian suatu permasalahan 
(Irwanto, Saputro, Rohaeti, dan Prodjosantoso, 2018). Terlebih lagi kemampuan pemecahan masalah calon guru sangat relevan dengan kemampuan dalam mengaplikasikan pengetahuan yang dimiliki yang tidak hanya berbasis konseptual tetapi berbasis faktual sebagai upaya dalam melatih keterampilan pemecahan masalah dalam menghadapi suatu persoalan dalam kehidupan. Dengan demikian, Pengembangan kemampuan pemecahan masalah calon guru pada umumnya, dan calon guru PAI pada khsususnya sangat urgen untuk dilakukan sehingga nantinya berdampak positif pada pencapaian kompetensi yang maksimal, bahkan sangat mendukung keberhasilan pencapaian karier di masa depan (Fadli, 2019). Akan tetapi, penelitian yang mengukur keterampilan pemecahan masalah di tingkat Perguruan Tinggi masih terbatas pada pengukuran pencapaian aspek kognitif (Ismiani, Syukri, Wahyudiati, 2017) sehingga saat urgen untuk dilakukan penelitian yang mengukur tingkat kemampuan pemecahan masalah calon guru sebagai bekal dalam menghadapi persaingan di era globalisasi.

Keterampilan pemecahan masalah calon guru tidak hanya dipengaruhi oleh penerapan model, metode, ataupun strategi pembelajaran yang diterapkan, tetapi juga dipengaruhi oleh faktor gender dan grade levels. Kondisi faktual tersebut sangat relevan dengan berbagai hasil kajian sebelumnya yang membuktikan bahwa gender dan tingkatan pendidikan memiliki pengaruh terhadap terhadap kemampuan Problem-solving skills (PSS) calon guru (Selcuk, Caliskan, \& Erol, 2007). Oleh karena itu, sangat urgen dilakukan penelitian untuk memetakan kondisi faktual keterampilan pemecahan masalah calon guru PAI yang masih jarang dilakukan sehingga dari hasil penellitian ini diharapkan dapat mendeskripsikan kemampuan Problemsolving skills (PSS) calon guru PAI di level perguruan tinggi berdasarkan gender dan grade levels.

\section{LANDASAN TEORI}

Problem-solving skills atau yang dikenal dengan istilah keterampilan 
pemecahan masalah merupakan keterampilan utama yang harus dikembangkan dalam praktek pembelajaran abad 21, selain keterampilan berpikir kritis, kemampuan komunikasi dan kolaborasi. Keterampilan pemecahan masalah didefinisikan sebagai kemampuan untuk mengidentifikasi, menganlisis, merancang atau merencanakan, melaksanakan atau mempratekkan, mengevaluasi, serta menemukan solusi dalam merumuskan jawaban baru untuk menyelesaikan suatu permasalahan (Erozkan, 2013; Caliskan). Selain itu, proses penyelesaian masalah meliputi proses identifikasi masalah, merumuskan masalah dan menyusun hipotesis, membuktikan hipotesis melalui kegiatan percobaan atau proses diskusi, serta memilih alternatif solusi yang paling tepat (Moreno, 2010).

Pengembangan keterampilan pemecahan masalah mahasiswa sangat urgen dilakukan sehingga mahasiswa memiliki keterampilan pemecahan masalah yang memadai di dalam menghadapi persaingan kerja di era globalisasi. Berbagai hasil penelitian yang telah dilakukan Irwanto, Saputro, Rohaeti, dan Prodjosantoso (2018), dan Temel (2015) membuktikan bahwa pengembangan keterampilan pemecahan masalah peserta didik sangat berperan dalam menentukan keberhasilan pserta didik di tingkat sekolah maupun di dunia kerja yang dihadapi nantinya. Terlebih lagi, kemampuan keterampilan pemecahan masalah terbukti memiliki pengaruh yang sangat penting terhadap kesuksesan hidup seseorang (D'zurilla, \& Nezu, 2007). Selain itu, kurangnya pengembangan kemampuan keterampilan pemecahan masalah yang dilakukan oleh dosen dapat menjadi penghambat utama untuk membangun dan mengaplikasikan proses belajar kognitif dalam rangka membangun konsep yang koheren (Su, 2016). Dengan demikian praktek pembelajaran yang merujuk pada pengembangan keterampilan abad 21 . Terlebih lagi di tingkat Universitas harus dapat mengembangkan keterampilan belajar yang sangat diperlukan mahasiswa dalam menghadapi masalah global sehingga menghasilkan lulusan guru pendidikan agama Islam yang kompeten dan siap menghadapai tantangan di era globalisasi. 


\section{METODE}

Pada penelitian ini menggunakan design Cross-sectional survey design yang bertujuan untuk mendeskripsikan kondisi dan situasi obyek penelitian dengan dua variabel atau lebih (Creswell, 2009). Penentuan sampel penelitian melalui teknik cluster random sampling Sampel penelitian sebanyak 100 orang calon guru PAI (60 perempuan dan 40 laki-laki) dari Universitas Islam Negeri Mataram yang terdiri dari junior (40\%), sophomore (30\%), dan freshman (30\%), serta 60\% perempuan dan 40\% laki-laki. Instrumen untuk mengukur kemampuan problem-solving skills (PSS) diadaptasi dari Instrumen problem solving essay test (PSET) yang dikembangkan oleh Polya (Polya, 1997). Instrumen PSET yang digunakan terdiri dari 4 indikator yaitu memahami masalah, merencanakan pemecahan masalah, melaksanakan rencana pemecahan masalah, dan melakukan kegiatan refleksi dan evaluasi. Data hasil penelitian dianalisis dengan uji MANOVA.

\section{HASIL DAN PEMBAHASAN}

Data dari hasil penelitian yang diperoleh berupa data kuantitatif berdasarkan hasil uji kemampuan PSET calon guru PAI. Data kuantitatif yang diperoleh dianalisis dengan uji Manova setelah dilakukan uji prasyarat terlebih dahulu, di mana data yang diperoleh termasuk dalam kriteria terdisribusi normal dengan nilai $\mathrm{p}>0.05$. Hasil multikolinieritas diperoleh nilai VIF sebesar 0.45 yang artinya tidak terdapat multikolinieritas, dan matriks scatter plot menunjukkan terdapat korelasi positif untuk setiap pasangan variabel (uji linieritas).

Berdasarkan hasil analisis uji Levene's test PSS diperoleh nilai p $>0.05$ (Tabel 1) yang menunjukkan bahwa tidak terdapat perbedaan variance sehingga diasumsikan sudah memenuhi prasyarat uji Manova.

Tabel 1. Hasil uji Levene's test (Uji homogenitas).

\begin{tabular}{|c|c|c|c|c|}
\hline & F & df1 & df2 & Sig. \\
\hline Problem-solving skills & .510 & 5 & 294 & .765 \\
\hline Overall & .593 & 5 & 294 & .705 \\
\hline
\end{tabular}


Setelah memenuhi prasyarat untuk uji Manova, selanjutnya dilakukan uji Manova yang menunjukkan bahwa terdapat perbedaan PSS berdasarkan grade levels $\mathrm{p}<0.05$ (nilai $\mathrm{p}$ lebih kecil dari 0.05), akan tetapi tidak ditemukan perbedaan berdasarkan gender karena diperoleh nilai p>0.05 (Tabel 2).

Tabel 2. Hasil Uji Manova PSS Berdasarkan Gender dan Grade levels

\begin{tabular}{|l|l|l|}
\hline \multirow{3}{*}{ Gender } & Effect & Sig. \\
\cline { 2 - 3 } & Pillai's Trace & .070 \\
\cline { 2 - 3 } & Wilks' Lambda & .070 \\
\cline { 2 - 3 } & Hotelling's Trace & .070 \\
\cline { 2 - 3 } & Roy's Largest Root & .070 \\
\hline \multirow{7}{*}{ Grades } & Pillai's Trace & .025 \\
\cline { 2 - 3 } & Wilks' Lambda & .025 \\
\cline { 2 - 3 } & Hotelling's Trace & .025 \\
\cline { 2 - 3 } & Roy's Largest Root & .025 \\
\hline
\end{tabular}

Temuan menarik penelitian membuktikan bahwa terdapat perbedaan PSS berdasarkan tingkat pendidikan, namun tidak terdapat perbedaan berdasarkan gender. Hasil penelitian yang diperoleh sangat relevan dengan hasil penelitian terdahulu yang menunjukkan bahwa terdapt perbedaan PSS calon guru berdasarkan grade levels (Arslan \& Karates, 2014). Fakta menarik tersebut membuktikan grade junior memiliki PSS yang lebih tinggi dibandingkan dengan grades freshman dan sophomore. Grade junior memiliki kemampuan PSS yang paling tinggi disebabkan oleh pengalaman belajar yang ditempuh sejak tahun pertama dan kedua sangat membantu dan memudahkan dalam meyelesaikan tugas-tugas pemecahan masalah pada tahun ketiga. Adapun kemampuan PSS calon guru PAI tidak memiliki perbedaan berdasarkan gender disebabkan oleh pengalaman belajar dan motivasi yang dimiliki oleh mahasiswa laki-laki dan perempuan cenderung merata.

Selanjutnya untuk mengetahui tingkat PSS calon guru PAI berdasarkan gender dan grade levels dengan merujuk pada nilai mean yang diperolah (Tabel 3 dan 4). Temuan penelitian mengungkap fakta menarik yaitu kemampuan PSS mahasiswa perempuan sedikit lebih tinggi dibandingkan 
dengan mahasiswa laki-laki (Tabel 3). Adapun untuk level PSS calon guru PAI menunjukkan kemampuan grade junior paling tinggi apabila dibandingkan dengan grade freshman dan sophomore (Tabel 4).

Tabel 3. Nilai Mean PSS Berdasarkan Gender

\begin{tabular}{|l|l|l|}
\hline \multicolumn{1}{|c|}{ Varibel Dependent } & \multicolumn{1}{c|}{ Gender } & Mean \\
\hline \multirow{2}{*}{$\begin{array}{l}\text { Problem-solving skills } \\
\text { (PSS) }\end{array}$} & Laki-laki & .900 \\
\cline { 2 - 3 } & Perempuan & .910 \\
\hline
\end{tabular}

Tabel 4. Nilai Mean PSS Berdasarkan Grade levels

\begin{tabular}{|c|c|c|}
\hline Varibel Dependent & Grades & Mean \\
\hline \multirow{3}{*}{$\begin{array}{l}\text { Problem-solving skills } \\
\text { (PSS) }\end{array}$} & Freshman (Mahasiswa semester 1) & .903 \\
\hline & Sophomore (Mahasiswa semester 3) & .915 \\
\hline & Junior (Mahasiswa semester 7) & .921 \\
\hline
\end{tabular}

Temuan hasil penelitian yang membuktikan (merujuk nilai mean) mengungkap bahwa level PSS yang paling tinggi dimiliki oleh grades junior. Hasil penelitian tersebut didukung oleh hasil penelitian sebelumnya yang membuktikan bahwa grade junior memiliki kemampuan PSS yang lebih tinggi dibandingkan dengan grade freshman dan sophomore (House, 1995). Adapun kemampuan PSS mahasiswa perempuan ditemukan sedikit lebih tinggi dibandingkan dengan mahasiswa laki-laki (0.910 dengan 0.900). Temuan penelitian tersebut juga relevan dengan hasil penelitian terdahulu yang menunjukkan bahwa level kemampuan PSS perempuan cenderung lebih tinggi dibandingkan dengan laki-laki (Selcuk, Caliskan, \& Erol, 2007). Adanya kecenderungan perempuan memiliki level PSS lebih tinggi dibandingkan dengan laki-laki juga dibuktikan oleh hasil penelitian yang diperoleh oleh House (1995) yang mengungkap bahwa perempuan memiliki motivasi, minat, dan kepercayaan diri yang lebih tinggi dalam mengerjakan tugas-tugas perkuliahan sehingga kemampuan pemecahan masalah yang dimiliki lebih berkembang sehingga berdampak pada peningkatan prestasi akademik yang dimiliki. 
Untuk memperdalam temuan penelitian ini dilanjutkan dengan tes uji Multiple Comparisons Tukey HSD untuk menganalisis kemampuan PSS calon guru PAI berdasarkan grade levels. Berdasarkan hasil tes Tukey HSD menunjukkan bahwa terdapat perbedaan PSS antara grade freshman, sophomore, dan junior karena diperoleh nilai $\mathrm{p}<0.05$ (Tabel 6).

Tabel 6. Hasil Uji Multiple Comparisons PSS dan SA berdasarkan Grades

\begin{tabular}{|l|l|l|l|l|}
\hline Dependent Variable & & Grades & Grades & Sig. \\
\hline Problem-solving skills & Tukey HSD & Freshman & Sophomore & .432 \\
(PSS) & & Junior & .453 \\
& & Sophomore & Freshman & .432 \\
& & Junior & .420 \\
& & Junior & Freshman & .453 \\
& & & Sophomore & .420 \\
\hline
\end{tabular}

Hasil penelitian membuktikan kemampuan PSS yang dimiliki terdapat perbedaan antara grade freshman dengan sophomore, grade freshman dengan junior, maupun antara grade junior dengan sophomore. Temuan berdasarkan hasil penelitian yang diperoleh juga relevan dengan hasil penelitian terdahulu yang membuktikan bahwa grade levels mempengaruhi kemampuan problemsolving skills yang dimiliki (House, 1995).

Kemampun PSS calon guru memiliki korelasi yang positif dengan dengan prestasi akademik yang dimilki oleh mahasiswa. Kondisi faktual tersebut didkukung dengan berbagai temuan penelitian terdahulu yang menunjukkan bahwa kemampuan PSS calon guru berpengaruh terhadap prestasi dan kinerja akademik calon guru (Selcuk, Caliskan, \& Erol, 2007; Fadli, 2019). Demikian juga dengan adanya perbedaan kemampuan PSS berdasarkan grade levels dapat menjadi pertimbangan utama dalam menentukan kebijakan, merancang kurikulum dan kegiatan pembelajaran, serta melaksanakan dan mengevaluasi proses pembelajaran di level Perguruan Tinggi dengan mengacu pada praktik pembelajaran abad 21. 


\section{KESIMPULAN}

Hasil penelitian mengungkap beberapa fakta menarik antara lain; (1) tidak terdapat perbedaan kemampuan problem-solving skills (PSS) calon guru PAI berdasarkan gender; (2) terdapat perbedaan kemampuan problem-solving skills (PSS) calon guru PAI berdasarkan grade levels; (3) grades junior (semester 7) memiliki level problem-solving skills (PSS) yang paling tinggi dibandingkan pada grades freshman (semester 3) dan sophomore (semester 5). Dengan demikian, berdasarkan temuan penelitian ini diharapkan dapat dijadikan acuan dalam menentukan kebijakan untuk merancang, melaksanakan, dan mengevaluasi proses dan hasil pembelajaran dengan mengacu pada pengembangan keterampilan abad 21 pada calon guru PAI di level Perguruan Tinggi.

\section{DAFTAR PUSTAKA}

Al-Attas, S. N. (1979). Aims and Objectives of Islamic Education, London: Hodder and Stoughton.

Arslan, C., Yavuz, G., \& Karates, D, Y. (2014). Attitudes of elementry school students towards solving mathematic problems. Procedia - Social and Behavioral Sciences, 152, 557 - 562.

Creswell, J. W. (2009). Research design: Qualitative, quantitative, and mixed methods approaches. Thousand Oaks, CA: Sage.

D'Zurilla, T. J., \& Nezu, A. M. (2007). Problem-solving therapy: A positive approach to clinical intervention ( $3^{\text {rd }}$ ed.). New York: Springer.

Erozkan, A. (2003). The effect of communication skills and interpersonal problem-solving skills on social self efficacy. Educational sciences Theory \& Practice, 13(2), 739-745.

Fadli, A. (2019). Problem-solving skills and Scientific Attitudes of ProspectiveTeachers Based on Gender and Grade levels. International Journal of Scientific \& Technology Research, 8(10). 
House D. J. (1995). Noncognitive predictors of achievement in introductory college chemistry. Res. Higher Educ., 36(4), 473-490.

Ibrahim, A.A., Hassan, S.S.S., \& Hashim, S. (2016). The effect of instructional video drama on students' perceptions on the observance of Islamic ethics: An experimental approach. International Journal of Education and Research, 4(10), 49-62.

Irwanto, Saputro, A.D., Rohaeti,E., \& Prodjosantoso, A.K. (2018). Promoting critical thinking and problem-solving skills of preservice teachers through process-oriented-guided-inquiry learning (pogil). International Journal of Instruction, 11(4),777-794.

Ismiani, S., Syukri., \& Wahyudiati, D. (2017). Pengaruh penerapan metode problem based learning terhadap sikap ilmiah dan hasil belajar biologi siswa kelas vii mts nw 01 kembang kerang. Biota, 10(1), 68-75.

Moreno, R. (2010). Educational Psychology. John Wiley and Sons.

Polya, G. (1957). How to solve it (2nd ed.). Princeton: Princeton University Press.

Sanabria, J. C., \& Jesús, A.-L. (2017). Enhancing 21st century skills with AR: Using the gradual immersion method to develop collaborative creativity. Eurasia Journal of Mathematics, Science and Technology Education, 13(2), 487-501.

Selcuk, G.S., Caliskan, S., \& Erol, M. (2007). The effect gender and grade levels on Turkish physics teacher candidate's problem-solving strategies. Journal of Turkish Science Education 4(1).

Su, K.-D. (2016). Strengthening strategic applications of problem-solving skills for Taiwan students' chemistry understanding. Journal of Baltic Science Education, 15(6), 662-679.

Temel, V. (2015). The problem-solving skills of the teachers in various branches. Educational Research and Reviews, 10(5), 641-647. 